University of Wollongong

Research Online

Sydney Business School - Papers

Faculty of Business and Law

$1-1-2020$

\title{
Career Capital Development of Women in the Arab Middle East Context: Addressing the Pipeline Block
}

Payyazhi Jayashree

University of Wollongong, payyazhijayashree@uowdubai.ac.ae

Valerie Lindsay

Grace McCarthy

University of Wollongong, gracemc@uow.edu.au

Follow this and additional works at: https://ro.uow.edu.au/gsbpapers

Part of the Business Commons

\section{Recommended Citation}

Jayashree, Payyazhi; Lindsay, Valerie; and McCarthy, Grace: Career Capital Development of Women in the Arab Middle East Context: Addressing the Pipeline Block 2020, 1-26.

https://ro.uow.edu.au/gsbpapers/587

Research Online is the open access institutional repository for the University of Wollongong. For further information contact the UOW Library: research-pubs@uow.edu.au 


\title{
Career Capital Development of Women in the Arab Middle East Context: Addressing the Pipeline Block
}

\begin{abstract}
Taking a career capital approach, this paper addresses the issue of 'pipeline block' frequently experienced by women seeking career advancement. Focusing on the Arab Middle East (AME) region, we take a contextually relevant multi-level approach to examine these issues. The study uses a qualitative, interview-based approach, drawing on data obtained from women leaders from the AME region. Drawing on Bourdieu's capital-field-habitus framework, we explore how women in the AME developed career capital in particular organizational fields. Our findings show the importance of human and social capital, as well as the influence of habitus for women's career advancement in specific fields. We also highlight the unique contribution of cultural capital in helping women to navigate organizational fields where it is necessary to both challenge, and conform to, traditional norms. Limitations of the study include assumptions of homogeneity across countries of the AME, whereas differences are known to exist. Future research should consider these contextual differences, and also include a study of women who were not successful in gaining career advancement. Our multi-level approach highlights practical implications for women, organizations, and society. For organizations, we propose some context-relevant coaching strategies that can help women to attain leadership positions. Our multi-level approach highlights practical implications for women, organizations, and society. Focusing on organizations, we propose some context-relevant coaching strategies that can help women to attain advancement in their careers. We demonstrate originality in our findings by showing how women overcome the pipeline block in relation to their career advancement. The use of the Bourdieusian framework, an in-depth qualitative approach, and the AME context also add to the study's originality.
\end{abstract}

\section{Keywords}

development, capital, middle, career, women, arab, block, pipeline, addressing, context:, east

Disciplines

Business

\section{Publication Details}

Jayashree, P., Lindsay, V. \& McCarthy, G. (2020). Career Capital Development of Women in the Arab Middle East Context: Addressing the Pipeline Block. Personnel Review, Online First 1-26. 


\section{Personnel F}

Career Capital Development of Women in the Arab Middle East Context: Addressing the Pipeline Block

\begin{tabular}{|r|l|}
\hline Journal: & Personnel Review \\
\hline Manuscript ID & PR-10-2018-0436.R2 \\
\hline Manuscript Type: & Research Article \\
\hline Keywords: & $\begin{array}{l}\text { Career Capital, Women, Bourdieu, HRD Strategy, Coaching, Pipeline } \\
\text { Block }\end{array}$ \\
\hline Methodologies: & Qualitative \\
\hline \multicolumn{2}{|l}{} \\
\hline
\end{tabular}

SCHOLARONE ${ }^{\text {m }}$

Manuscripts 


\section{CAREER CAPITAL DEVELOPMENT OF WOMEN IN THE ARAB MIDDLE EAST CONTEXT: ADDRESSING THE PIPELINE BLOCK}

\section{Purpose}

Taking a career capital approach, this paper addresses the issue of 'pipeline block' frequently experienced by women seeking career advancement. Focusing on the Arab Middle East (AME) region, we take a contextually relevant multi-level approach to examine this issue.

\section{Design/methodology/approach}

The study uses a qualitative, interview-based approach, using data from women in the AME region. Drawing on Bourdieu's capital-field-habitus-doxa-illusio framework, we explore how these women developed career capital in their respective organizational fields.

\section{Findings}

Our findings show the importance of human and social capital, as well as the influence of habitus for women's career advancement in specific fields. We also highlight the unique contribution of cultural capital in helping women to navigate organizational fields where it is necessary to both challenge, and conform to, traditional norms.

\section{Research limitations/implications}

Limitations of the study include assumptions of homogeneity across countries of the AME, whereas differences are known to exist. Future research should consider these contextual differences, and also include a study of women who were not successful in gaining career advancement.

Practical and social implications 
Our multi-level approach highlights practical implications for women, organizations, and society. Focusing on organizations, we propose some context-relevant coaching strategies that can help women to attain advancement in their careers.

\section{Originality/value}

We demonstrate originality in our findings by showing how women overcome pipeline block in relation to their career advancement. The use of the Bourdieusian framework, an in-depth qualitative approach, and the AME context also add to the study's originality.

Keywords: career capital, women, pipeline block, Bourdieu, coaching, HRD strategy. 


\section{INTRODUCTION}

Pipeline block refers to a bulging/bursting of the management pipeline, as seen in the lower representation of women in senior positions across sectors (Afiouni, Karam, and Sidani 2014; Karam and Afiouni, 2014). Globally, the proportion of women in management positions is $25 \%$, and in board positions, $17 \%$ (Thornton, 2019), indicating that pipeline block for women is a global phenomenon. Both women and organisations must devise strategies for overcoming pipeline block in order to advance women to leadership positions. Although studies of pipeline block and barriers to women's career advancement are numerous, only recently has the influence of context, such as national political, economic and socio-cultural environments, and organizational differences, been recognized as influential. However, relatively few studies on women's career advancement within the AME context relate to pipeline block.

Labor market inequalities persist within the North Africa and Arab region, with the employability rate of women being half that of men (ILO, 2018), and even greater disparities evident for senior management positions across the AME (Kemp et al, 2015). This is despite the increasing number of qualified and skilled women in the region (Karam and Afiouni, 2014). To date, research has not adequately addressed contextually relevant HRD interventions for overcoming pipeline block and progressing women's careers and leadership potential in the AME (Karam and Jamali, 2013). In fact, little is known about how context matters in this regard, and, accordingly, how multiple levels interact and influence women's careers. The objectives of this study are, therefore, to provide insights into (i) how individual and other contextual factors influence career capital and career advancement of women in the AME region; and (ii) how these can be interwoven with HRD (specifically coaching) strategies to provide better career development outcomes for these women. We refer to context as the 
macro- (societal) and meso- (organizational) level environments, micro-level (individuals), and gender (women).

Our study addresses recent calls in the literature for (i) research on career capital to include a gender context and account for diversity of experiences in career development (Huppatz, 2009); (ii) increased attention to multi-level contextual influences in HRM research (Renkema, Meijerink and Bondarouk, 2017) and in leadership development (Karam and Affiouni, 2014), and (iii) more contextually-sensitive studies in HRM, since traditional Western theoretical foundations concerning women and career development may not be generalizable to nonWestern contexts (Tlaiss, 2014b).

Such research should seek to theoretically and empirically explore initiatives to address, overcome, or sidestep sources of the pipeline block, both within, and outside, the organization. Karam and Afouni (2014) argue that the roots of individual gendered behaviours and actions lie not only within organizations, but also in societies and institutional mechanisms outside of organizations. Hence, addressing the pipeline block requires a contextually holistic and multilevel approach. This allows the identification of significant interdependencies and influences across levels, adding theoretical and practical relevance to the findings (Rousseau and Fried, 2001). As Karam and Afiouni (2014, p.502) state, “a multilevel perspective will allow HR practitioners to take more informed decisions concerning the development of the HR function in the Arab MENA ${ }^{1}$, to match the changing landscape of gender relations".

In framing a multi-level contextual approach to the issue of women's career development in this study, we draw on Bourdieu's conceptualisation of capital, field and habitus, as well as the

\footnotetext{
${ }^{1}$ Middle East North Africa
} 
Bourdieu's capital-field-habitus framework is used extensively to examine career development in HRM (Fitzsimmons and Callan, 2016) and, more recently, in the sub-field of migration studies (Erel, 2010). Using the Bourdieusian approach, we aim to extend the women's career development literature in several ways. First, we explore the different types of capital accumulated by women in different contexts. Second, we take into account the socio-cultural context of the country/region (predominantly collectivist and patriarchal) in which the women have gained experience and operate. Third, we highlight the role of cultural capital, which, we propose, plays a key bridging role across traditional socio-cultural divides impacting women's career advancement, in particular, acting as a bridge between habitus and field. Fourth, by combining these perspectives, we offer a conceptualisation of career capital that is contextually relevant to the AME. Last, we propose contextually relevant HRD (specifically coaching) strategies and interventions that can help women to advance their careers in this region. We also seek to add to the small pool of exploratory research in this area, thus responding to the 
call for more qualitative studies that explore the links between career capital and career experience (Duberley and Cohen,2010).

Since we are concerned with examining the challenges and barriers to career progression of women in the AME region, and, by extension, the relevance and appropriateness of traditional views that tend to perpetuate these challenges, our study lends itself to a critical theory perspective. This perspective "does not simply relate to being critical of existing theory, but, through the application of dialectical thought, allows a researcher to view alternative explanations for established or observed phenomena, without necessarily negating the traditional view (Carr, 2006; Brookfield, 2014)." (cited in Yu and Lindsay, 2017, p.298). The core of critical scholarship is reflected in the notion of radical critique, which is attentive to "socially divisive patterns and structures, such as [patriarchy]...", among others (Adler, Forbes, and Willmott, 2007, p.120). While we do not use critical theory as a core theoretical lens for our investigation, we find it a useful perspective to help interpret and make sense of our findings, as we refer later in the relevant sections.

\section{PIPELINE BLOCK IN THE AME}

The employment participation rate of women is considerably less than that of men in the AME region, and, although there are steady reductions in the gender employment gap (e.g. 64\% of the gap reduced in the UAE), the gap is wider than the global average (The Global Gender Gap Report, 2020). Despite significant increases in women employed in legislative and managerial positions in the UAE (UAE Embassy, 2020), evidence of pipeline block still exists (Marmenout and Lirio, 2014). For example, women's share of managerial positions, relative to men's, in the UAE is $15.8 \%$ (ILO, 2018). While this reflects the top performance by a country in the 


\begin{abstract}
AME region, it also provides clear evidence of women being stuck in the career development pipeline.
\end{abstract}

The literature highlights many reasons for lack of career progression by Arab women in the region. At an individual level, Arab women appear to conceptualise career success differently to Western women, seeking greater alignment with their cultural values, rather than more hedonic rewards (Jayashree and Lindsay, 2016). Organizationally, aspects such as limited maternity leave and access to child-care facilities are reported as impediments to women advancing their careers in the AME region (Karam and Afiouni, 2014; Rayfield, 2019). Familial and cultural considerations also restrict the pursuit of global careers and international assignments for women in the AME, with researchers calling for HR strategies to better align talent management strategies with these considerations (Hutchings, Lirio and Metcalfe, 2012; Tlaiss, 2013; Tlaiss, 2014 a,b). Institutional contexts (Karam and Jamali, 2013) also impact women's career advancement, and, hence, contribute to the pipeline block in the AME region. In the case of Lebanon, Sidani, Konrad and Karam (2015) found that cultural-cognitive forces (specifically religion and family) shape normative expectations regarding traditional gender roles, and, when intertwined with barriers within the legal framework, limit career development opportunities for women. In the UAE context, the need for better implementation of supportive legislation has also been noted (Forstenlechner, Madi, Selim and Rutledge, 2012).

Given this, and other research, the contention of the 'bursting pipeline' (Karam and Afiouni, 2014) being a major issue for skilled women in the AME is widely supported. Various factors at multiple levels appear to impede the ability of talented women in this region to attain career progression to senior levels in the organizations in which they work. 


\section{THEORETICAL BACKGROUND}

\section{Career Capital}

The literature presents definitions and frameworks for career capital that, while different operationally and in scope, are rooted in the Bourdieusian framework. For example, DeFillippi and Arthur (1996) introduced the notion of career capital to their concept of boundaryless career, applying a competency-based perspective based on 'three ways of knowing'. Mayrhofer, Meyer, Styrer, Maier, and Herman (2004) built on the social structure - individual agency relationship, utilising Bourdieu's work to further explain career capital. Fitzsimmons and Callan (2016) define career capital for CEOs as a combination of human, psychological, and social capitals, as well as several dimensions of working experience (track record). Based on Bourdieu's underlying forms of capital (economic, social and cultural, and, later, symbolic capital), career capital represents the combination of particular forms of capital that are valued by the particular field (Duberley and Cohen, 2010).

\section{A Bourdieusian Perspective}

Research suggests that women may be unable to reach higher level positions because they lack strategic understanding and experience normally derived from line management or strategic roles early in their career. As a result, they are unable to develop relevant career capital (Eagly and Heilman, 2016; Fitzsimmons, Callan and Paulsen, 2014). The Bourdieusian framework provides an interpretive lens of capital, field and habitus to examine career trajectories and the factors that can impact subjective career experiences of divergent cohorts (Bourdieu 1990). This perspective allows for multiple interacting levels, notably individual, organizational and societal, to be considered, ensuring a holistic contextual view of the phenomenon. 
Capital is defined by Bourdieu as "all goods, material and symbolic, without distinction, that present themselves as rare and worthy of being sought after in a particular social formation." (Bourdieu, 1977, p.78). In Bourdieusian terms, capital refers to economic capital (financial resources, or access to wealth), social capital (access to networks, social relationships and memberships in relevant groups), and cultural capital, including 'institutional' (e.g. academic qualifications), 'embodied', (e.g. previous work experience, ability to speak different languages, or relevant cross-cultural experiences), and 'objectified' (e.g. through artefacts, dress, or other material manifestations). When these forms of capital (economic, social, and cultural) are mobilized in appropriate ways to gain power, then symbolic capital is gained, as evidenced by the social ranks or positions that are accorded to actors in the social hierarchy (Joy, Game, and Toshniwal, 2018).

Fitzsimmons and Callan (2016) refer to career capital as comprising human, psychological and social capital that are relevant to the career development of CEOs. These each have several sub-components: human capital (comprises strategy, leadership, cognitive skills, integrity, and stewardship); psychological capital (comprises self-efficacy, and self-awareness); and social capital (comprises visibility). The authors also note the importance of context, such as environmental uncertainty. The capitals are 'validated' by the individual demonstrating a 'track record', comprising contextual and other experiences. Social capital, expressed through networks and visibility, was found to be the most important for career progression to CEO level.

Field, in the Bourdieusian (1990) framework, reflects "a social space in which players are positioned with given resources" (Glover, Champion, Daniels, and Boocock, 2016, p.27), with shared rules by which the players earn their legitimacy. The field is occupied by dominant 
members who define the implicit rules (doxa), and what is considered as valuable capital within the field. The 'rules' and 'value' ascribed to capital tends to mirror the vision and habitus of the dominant cohort. A social order or hierarchy ensues within the field, based on the players and their accumulation of what they perceive as valued capital, such that those with less valued capital have less bargaining power in the field (Joy et al., 2018). For example, corporate contexts that are largely male dominated are structured in such a way that specific configurations of competencies (e.g. intellectual and social capital) are considered valuable to reach, or succeed in, leadership positions (Fitzsimmons and Callan, 2016a). Further, the contexts for capital creation often replicate and impose the dominant cohort (male) perceptions and frames of reference, thereby attracting those who embody similar capital (other males), and excluding those who do not (Golsorkhi et al, 2009).

According to Bourdieu, habitus is "a disposition, tendency, propensity, or inclination" (Bourdieu, 1977, p. 214, cited in Bourdieu and Wacquant, 1992, p. 18). Habitus reflects learnt assumptions and behaviours, as internalized through early socialisation experiences (Kelly and Lusis, 2006), most notably in the family setting, as well as other influences throughout life, such as education, and media (Joy et al, 2018). Habitus defines the individual's approach to gaining recognition of the value of his/her various capitals in a specific organizational field. According to Bourdieu, although habitus is an essentially durable quality, it can be transformed or re-invented in situations where the individual moves to an unfamiliar field, or where it no longer fits with the field. Habitus has been identified as laying the foundation for leadership capacity development (Fitzsimmons et. al., 2014). Lawler (2005, p. 113) argues that habitus is a "factor of inequality", since it gives power based on the person his/herself, rather than what they have or can do. 
Doxa is described by Bourdieu (2000, p. 100) as "a set of inseparably cognitive and evaluative presuppositions whose acceptance is implied in membership itself' (to the field)" (cited in Golsorkhi et al, 2010, p. 785). Doxa represents the taken for granted assumptions that reflect commonly held beliefs, reinforce domination in the field, and become unquestionable and unchallengeable (Golsorkhi et al, 2010). Illusio refers to the 'game' that is played by dominant actors within a field, with those actors having an unconscious belief in the interests of, and stakes in, the game. Illusio reflects a shared illusion that is also described as a "collective selfdeception" (Golsorkhi et al, 2010, p. 784), and, through the collective playing of the game, becomes self-reinforcing. Doxa and illusio thus reflect the unwritten rules and beliefs, and the accepted ways in which the game is played in a given field, within which assumptions about what constitutes valued capital are made and legitimized.

\section{Career Capital and Women}

Research addressing the inability of women to develop the 'career capital' needed for career advancement has been largely ignored in previous literature (Duberley and Cohen, 2010; Fitzsimmons et al. 2014). Fitzsimmons et al propose that multiple factors interact at the level of individual, organization, and society, at different stages of the organizational life-cycle and in different contexts, to limit a woman's ability to acquire valued career capital. Specifically, these authors found that the disparity between the number of male and female CEOs was related to the types of capital accumulated, the ways they were accumulated, and differences in men's and women's habiti. For example, gender-oriented childhood experiences, such as boys being channelled to sports, and girls to home-making, have been shown to impact habitus and the early formation of various types of capital (Fitzsimmons et al., 2014). Further, Fitzsimmons and Callan (2016a) found that various forces at the level of individual, organization, and society act in a reciprocal manner to exclude women from the contexts that are critical for developing 
valued capital. This is particularly evident in middle management positions, when responsibilities for child-care and ageing parents, and work-life balance, may impede women's advancement at this stage of their career.

\section{HRD Strategies and Coaching}

The literature suggests that any HRD intervention to dissipate the pipeline block experienced by women in the AME must be contextually relevant and founded on a holistic understanding of the forces operating at multiple levels (Elbanna, 2010). The impact of context (societal and organizational fields, as well as gender) and the individual's habitus, on the formation and leveraging of valuable capital, are central to an effective HRD strategy for women's careers advancement. Coaching is foundational to such HRD strategies in promoting the development of career capital and reducing pipeline block (Bonnywell, 2017).

The terms coaching and mentoring are often used interchangeably and they utilize many of the same skills in the coach or mentor, e.g. listening, questioning, goal setting and feedback (McCarthy 2014). Mentoring is a more informal and less structured process than coaching, usually adopted voluntarily among individual employees (Abdalla, 2015). Coaching, as a more formal and structured process, "represents an area of practice roles and workplace behaviors, within the field of HRD that has considerable potential for enhancing individual, group/team, and organizational growth, learning, development, and change" (Ellinger and Kim, 2014 p.8). Coaching enables individual and organizational change (Koroleva, 2016), and enhances leadership self-efficacy (McDaniel and DiBella-McCarthy, 2012) and organizational learning (Hagen and Gavrilova Aguilar, 2012), leading to employee engagement (Dello Russo et al. 2017), and improved performance (Lin, Lin, and Chang, 2017). Group coaching (Bonneywell, 2017) and peer coaching (Bozer and Joo, 2015) can help to develop social capital, while 
individual coaching may develop psychological capital, particularly self-awareness and selfefficacy (Bozer and Joo, 2015).

The coaching process must be culturally appropriate, in order for leaders to leverage cultural capital (Gormley and van Nieuwerburgh, 2014). However, the literature has been criticized for being too narrowly focused on Western contexts, thus questioning its relevance to the Arab region (Elbanna, 2010). What little research exists in the AME, suggests that formal organizational coaching in the region is in its infancy, despite increasing demand from women (Leimon, Moscovici and Goodier, 2010). On the other hand, informal individual-individual mentoring, especially among women, appears to be quite prevalent (Kemp et al, 2015). Almessabi (2017) identifies the lack of a coaching culture and managerial coaching skills, as significant barriers to the implementation of leadership succession planning in UAE public sector organizations. Others report the reluctance of employees to discuss career goals with managers, or actively seek leadership development opportunities (Klima, 2015).

While the objectives of coaching for women, including developing confidence, overcoming prejudice and gaining of work-life balance are universal (Leimon et al, 2010), research indicates the benefits of contextual adaptation of coaching in the AME. For example, Palmer and Arnold (2013) report that gathering 360-degree feedback from influential external stakeholders can be a powerful input to coaching and behavioural change in the Arab context, thereby making use of the dominant power holders to 'hold a ladder', in line with the Arab proverb: "No one can escalate except those who have a ladder" (Taymor, 1986, p.107, cited in Mohamed and Mohamad, 2011, p. 415). Coaching can also promote a healthy business climate and foster good cross-cultural communication skills, reducing the complexities associated with building leadership and career competencies in the Middle East (Al-Nasser and Behery, 2015). 
However, the extent to which contextually-relevant coaching can alleviate the pipeline block in the AME requires considerably more research.

\section{METHODOLOGY}

Consistent with approaches to exploratory research used for examining phenomena in depth, our study utilized a qualitative methodology (Edmondson and McManus, 2007).

\section{Participant Selection}

The UAE is somewhat unique in having a predominantly expatriate workforce and this applies at all levels of employment. The majority of employers are local, Arab, or South Asian, and all share a dominant collectivist and patriarchal culture. The women participants in our study were a mix of local Emirati and expatriates, mainly from the $\mathrm{AME}^{2}$ (including North Africa) region. The study investigates their experiences working and building their careers in the AME/North Africa region and specifically in the UAE.

Individual women were the unit of analysis. We relied on these key participants to provide data on their perceptions of their career advancement journey from a multi-level perspective. Specifically, we addressed matters relating to them as individuals, and explored their understandings of the roles that organizations and society had played in their career development trajectory, thus exploring multi-level influences from the time of their childhood. Since all the women had considerable work experience, including senior management or leadership positions in the UAE, they were able to reflect on the wide range of challenges and

\footnotetext{
${ }^{2}$ We include women from two North African countries, Sudan and Morocco, a part of the Arab Middle East. While the countries are all part of MENA (Middle East North Africa) (https://www.worldatlas.com/articles/whatare-the-mena-countries.html), this region includes non-Arab countries. Hence we refer to AME to include the Arab countries listed, as well as the two predominantly Arab North African countries noted.
} 
drivers experienced during their career journeys. The majority had spent most of their careerbuilding life in the UAE or wider AME / North Africa region.

Participants were first identified from the membership database of the Dubai Business Women Council (DBWC), after being filtered according to agreed criteria. These included: their home country being within the AME / North Africa region, being an organizational employee or business owner; having substantial work experience in the UAE; having at least 5 years' experience working at a senior / leadership level; and working in the UAE at the time of the study.

Although our database search revealed many more eligible participants, fourteen women were purposively selected for the study. These women demonstrated the best overall fit with the criteria, provided variation in their origins across the AME region, and had diverse organizational backgrounds. The remaining eligible women were available to participate in the study should additional data be deemed necessary by the researchers, as the data analysis proceeded.

All the participants had origins in the AME (including North Africa) region, including UAE, Lebanon, Morocco, Saudi Arabia, Jordan, Egypt and Sudan. One woman from Ghana lived in the UAE from an early age. Ten of the women worked in the private sector, three in family businesses, and one in an NGO. The sectors in which they were working at the time of the study included health, education, oil and gas, media, banking, consultancy, and retail. Educational qualifications included Bachelor's and Master's degrees, with one participant having a $\mathrm{PhD}$ degree. Their ages ranged from early 30 s to late $60 \mathrm{~s}$. (See Table 1). Once selected, the women were invited by the researchers by email to participate in the study. There 
was an overwhelming willingness to participate, and, once confirmed, interview dates and times were arranged.

\section{INSERT TABLE 1 ABOUT HERE}

\section{Data Collection and Analysis}

A semi-structured questionnaire was developed, with a primary focus on exploring career capital accumulation and career experiences of the women in the study, while allowing scope for exploration into other factors that participants considered relevant or had not previously not identified by the researchers. The face-to-face interviews were, therefore, framed broadly within existing concepts, but, through the use of open-ended questions (Crouch and McKenzie, 2006), sought to gain deeper insights by exploring contextual variations and new perspectives. The interviews took place either at the women's place of work, or at a neutral venue, such as a hotel or coffee shop. Interviews lasted 1-2 hours, were conducted in English, audiotaped and later transcribed.

The coding approach was guided by the work of Gioia, Corley and Hamilton (2012), and the coding procedure of Miles and Huberman (2004), as discussed further in this section. The software package, NVivo 11, was used to analyze the transcribed data, enabling a logical path of data coding and interpretation to be followed (Auld, Diker, Bock, Boushey et al., 2007; Yin, 2014). Each interview was treated as a 'case' and both within-case and cross-case analysis was conducted (Miles and Huberman 2004). The data were coded using a thematic approach (Cresswell, 2013), drawing initially on induction, or 'first order' concepts (Gioia, et al, 2012). Driven entirely by the data, this coding process commenced with open coding, and codes were then grouped into themes and patterns using an axial coding procedure; this helped to identify 
key concepts and their patterns of interaction within and between the cases (Miles and Huberman 2004; Strauss and Corbin 1998). In the 'second order' thematic process (Gioia et al, 2012), the concepts were then 'matched' to concepts from the literature, being guided partly by the broad pre-conceptualisation underpinning the interview questions.

Relationships within and between first and second order codes were further identified, in a process of 'system closure' (Miles and Huberman 2004). This provided the opportunity to propose some potential explanations of how and why particular effects and behaviours were evident, as well as contribute further insights to the literature through the inclusion of rich contextual information (Auld et al., 2007). Second order themes were then aggregated, where relevant, to provide an overarching set of high-level concepts. The analytical theme-building process continued across the interviews until the data provided no further insights, arriving at a position of theoretical saturation (Glaser and Strauss, 1967). This was evident when no new themes emerged from the data analysis, and when the second order theme building and system closure revealed a stable structure. Figure 1 shows the resulting data structure, based on first order concepts, second order themes, and aggregate dimensions, according to the approach recommended by Gioia et al, 2012.

\section{INSERT FIGURE 1 ABOUT HERE}

\section{FINDINGS AND DISCUSSION}

The findings are framed within the Bourdieusian constructs of capital, field, habitus, doxa and illusio (Bourdieu, 1990), with a specific focus on interactions and relations between these concepts (Glosorkhi, et al, 2009), and how they are reflected in practice. Our findings show that participants have a clear understanding of the field and the prevailing doxa and illusio in 
their particular situations. Habitus, developed in their early years, provided the impetus for perceptions and implicit assumptions regarding self. It also laid the foundations for the formation of valued capital, including human, psychological, social, and cultural capital, and, ultimately, career capital. Capital formation was further strengthened in later years through interactions with the field; this presented both challenges and opportunities for learning, supported by mentors and sponsors, but in no cases, by coaches. Thus, capital formation processes themselves are evidenced as outcomes of conscious choice and unconscious accumulation in varied contexts. This, in turn, enabled the participants to deploy practices to overcome career barriers, mainly through influencing the doxa and illusio dominating their organizational fields. These findings are discussed in detail below, along with illustrative quotes from the interviews. While we have structured this section according to distinct constructs and themes, we also highlight their interwoven and interdependent nature. Figure 2 shows our conceptual framework of career capital (drivers and outcomes), generated from the data structure and detailed findings.

\section{INSERT FIGURE 2 ABOUT HERE}

\section{Habitus}

\section{$\underline{\text { Early Socialisation Experiences }}$}

Participants discussed the ways in which their early socialisation impacted the development of their habitus. Their family experiences, particularly support from fathers, allowed them to develop agentic behaviours that provided the appropriate habitus for overcoming subsequent organizational career barriers. Habitus is the key quality that enables individuals to leverage the value of their capitals in a specific field (Fligstein and McAdam, 2011) and our findings support this view. As Bourdieu notes (1990), while habitus is durable, it can also be reinvented 
or transformed if the individual enters a new field, or their existing habitus does not fit. Many of the women deliberately sought to reinforce the agentic behaviours and practices developed early in life, during their working lives.

A strong and supportive father was instrumental in developing a powerful sense of self, and building beliefs of gender equality. Early opportunities to exercise leadership, through their father's support and/or enabling teachers in school, led to the development of valued capital, particularly human and psychological capital.

I always go back to the way my father raised me, He always used to tell me that, "Don't deal with men like you are a woman. You are no less than them. Deal with them a man to man. You have the brain of a brilliant man. You're not less than them. (Participant 12)

Family was seen as the unit where the women had a sense of identity and voice, thus being a significant predictor of later agency. The family environment normalized gender equity and egalitarian views, conferring an appreciation of privilege, since, at that time, traditional gender roles were still prevalent.

With my father's support, I had the same opportunity that my brothers did. My parents didn't believe that we should waste our time, so every summer I used to get French, Spanish lessons, join in to learn [other] languages as well. I learned typewriting... tennis, squash - like all sports that, you know, at that time, when it wasn't really available. So... I think I was lucky in the sense of having access. I had such morale and such independence and authority in my own family, I was able to move on with it in life and develop leadership (Participant \#1) 
Another significant driver of capital creation was female role models during early socialisation, especially within the family.

And the women in our family were generally inspirational. My grandfather, all his daughters, were educated at a time when Sudan didn't educate women. So they are very opinionated, they have their own dynamics, and they are generally very independent women. (Participant \#13)

In parallel with wider society, family was also instrumental in cementing strong cultural values and subsequent cultural capital that would become particularly significant in the women's career development. These early experiences provided the foundational learning for women to make conscious choices, actively negotiate, experiment, and take risks, through their career pathways. Habitus, and the capital development that it nurtured, thereby helped to mitigate the impact of impediments experienced by the women as their careers progressed. Their habitus embodied a level of agency that would serve them effectively at those times.

\section{Early Career Experiences}

The human capital (notably leadership and cognitive capital) and psychological capital (particularly self-awareness and self-efficacy) developed in childhood led the participants to consciously seek learning opportunities for growth, and further strengthen their capital.

When I graduated, what I wanted to do is work in a place where I can grow and evolve and learn, and I can, you know, give something. I mean, influence something, to be creative. I wanted a career that could give me room to grow (Participant \#9)

The pathway was not always smooth, and participants correspondingly demonstrated resilience and adaptiveness. Adversity was often the driver for seeking new challenges, where 
participants chose a growth- rather than execution-mindset, even though many challenges were not without risk.

My father's death pushed me out of Lebanon. His (my father's) loss was very great. Even now, today, if I think about it I feel I want to cry. [...]All my family supported me, and I think that is a blessing as well. They told me, "Go try. If you don't like it, you come back". It was a risk I took, in that young age, in the nineties, where - I think I do not know any other single female that left her parents from our environment. (Participant \#6)

\section{Field, Doxa and Illusio}

The field of particular importance in our study is the organization, although we also recognize the influences of society and family - the former in shaping, reinforcing, and legitimizing the organizational field, as well as family values, and the latter more directly influencing the habitus of individual women, as already discussed.

When the dominant cohort in the organization is male, women are unlikely to embody the specific configuration of capital that is valued, and are excluded from senior or leadership roles (Golsorkhi et al, 2009). Further, a lack of alignment of habiti between the dominant actors in the field and the individual can also mean that the individual is less able to promote the value of her/his capital, even if it would, otherwise, be valued (Erel 2010).

Patriarchal assumptions of gendered roles are reproduced in the field, consciously and unconsciously, to legitimize the power structure of the field. This is especially evident in the case of child- and family-care. While having a family is usually seen in an organization as a positive attribute for men, denoting stability and responsibility (Tharenou, Latimer, and 
Conroy, 1994), for women, it is invariably regarded negatively, implying lack of organizational commitment and loyalty (Bernhardt, 2000).

[...] motherhood and maternity are one of the major reasons why women have to drop out of work to take care of their families. Especially because we live in a region where family values are very important and women are expected to take care of their families first. (Participant \# 6)

While the literature notes child-care responsibilities as a key reason for women leaving the workforce (Benhardt, 2000), this is even more pronounced in the context of the AME region (Tlaiss, $2014 \mathrm{a}, \mathrm{b})$. Cultural expectations concerning responsibilities for child- and familycare in the Arab region are often shared by both women and men. For women, however, these responsibilities have emerged as a key factor leading to capital erosion, both 'symbolic' (as perceived) and 'material' (as happens).

We live in a region where family values are very important and women are expected to take care of their families first. "Being an expatriate, we do not have access to social nurseries or extended families, as in home countries. And the question would remain, do you want to keep your children 9-10 hours a day with a nanny that probably does not speak your language, does not know your culture, does not know how you want to raise your children. This also contributes for the decision that women do not go back to work. (Participant \#6)

Familial obligations tended to intersect with career progress at crucial points of time, often leading to a lack of advancement (pipeline block), or, causing the women to leave the organization (leaking pipeline). 


\section{1}

In our region, the GCC, family is very important. [...]And unlike in the West, you know, extended families come into consideration, or ageing parents... so a woman in her thirties or forties has a lot on her plate. She has to take care of kids, you know, teaching, working, social functions. Also older parents. So, all of this comes at the time where the progression in her career is at the highest. (Participant \#2)

As the above quotes illustrate, patriarchal assumptions operate as a veil, often without conscious thought, reflecting the habitus of the dominant cohort. These assumptions become the doxa that legitimizes their practices, keeping the organizational power structures intact (Bourdieu, 2000), and, in this study, precluding the participation of women. The predominant perception of our participants was that the dominant habitus was highly influenced by prevailing social rules about gendered roles.

I noticed, also, there was discrimination, in hiring women... Sometimes, informally, managers - I used to hear them talking. Or, 'let's hire a woman who is old - her kids are old,' because the women that's in her thirties or late twenties, is the women they avoided.[...]. And if she's in child-bearing age, they think of maternity leave. They think of all of that, but they never say it aloud. (Participant \#2)

However, one woman with considerable senior-level experience alluded to the possibility of challenging and changing the prevailing doxa in male-dominated organizations.

I can't say that my journey (in this very male dominated profession) has been smooth and without any challenges. But I detected that, in a Board room or in an executive room, the recipe was very simple. Whenever I've seen men lacking the ability in interacting with very strong women ... it is simply a matter of lack of experience and lack of exposure - men who have interacted (previously) with very strong female role 


\begin{abstract}
models - whether at home - be their mothers, be their wives, be their daughters these men interact very differently in the workplace. [For me], it was always about producing consistently credible, quality advise, because if you are consistent in the way you behave - in the way you deliver - very soon it becomes the norm. (Participant \#4)
\end{abstract}

Participants were also acutely aware of the game being played (illusio) in their organizations, and how the dominant subcultures found in different industry sectors were setting the rules (doxa) for the field; for example, in the media sector. Expectations of what a woman's role might, or might not, be in the organization, clearly affected the career progression of one of the participants, being generally excluded from participating in the game; hence, the dominant structure and practices were perpetuated. The 'game' was, therefore, legitimized, as the dominant actors played out scripts developed in their own habitus, in accordance with the concept of 'illusio' (Bourdieu, 1990).

When I joined the TV, most men in the Gulf were not thinking that the Emirati or the local ladies from the Gulf or MENA countries are, or should go into, media or TV. They think of it as a very dirty field, for girls with bad reputation. And at some point, they (men in media) were picking (recruiting) these women with bad reputation actually.... And, yeah, to show, you know, just their point. It was like, irritating them to say that women and Arab women with character and competence could go into media (Participant \#12)

All the participants considered exposure to strategic portfolios in their organizations vital for making career progress. However, because organizational reintegration of women returning to the workforce were considered minimal, there were limited opportunities for accumulating 
capital considered valuable in the specific field. As noted by Fitzsimmons et al (2016), career progression to $\mathrm{CEO}$ level, and the successful management of strategic imperatives, requires relevant configurations of human, psychological and social capital, as well as track record. Our participants pointed out that maintaining an unbroken track record and social connections is very difficult, especially with family responsibilities.

It's one thing to have a policy that says, 'You can take a year off work when you start your family.' but if in that year [...] I've been squeezed out of my role because somebody else has [...] taken over, chances are [...] I'm only going to take two weeks off, right? (Participant \#11)

\begin{abstract}
A key thesis of the Bourdieusian framework is that the greater the alignment between capital valued in a particular field, and capital accumulated by individuals, the greater the likelihood of the individual's ascent to leadership positions in specific fields (Fligstein and McAdam, 2011). Lovell (2000, p. 28) states that "capitals possessed, the composition of that capital, its trajectory over time and the control over its deployment" by men and women need to be understood, if we are to confront the persistent gender disparity in leadership roles. Dominant players in the field dictate what is considered as rare and worthy capital; hence access to power and status in that field is contingent on the accumulation of specific types and configurations of valued capital (Silva and Edwards, 2004). Iellatchitch, Mayrhofer, and Meyer (2003) point out that career capital is 'Janus-faced'; thus, what is espoused as valued capital in a field may not be what is valued outside of that field. This has particular relevance to the concept of flexitime or part-time employment for expatriate women. In the case of the UAE, the cost to the organization of required visas and insurances are often seen in organizations as a disincentive to follow this hiring practice.
\end{abstract}


I think policies regarding flexitime are there to make companies look great and attractive. But, I'm not sure that the policies are enforced necessarily - or if people are held accountable for rolling it out effectively. So if I knew as a male boss that my yearend review or my bonus is going to be based on how many people - how many women get reintegrated into the workforce successfully after maternity leave - I'm probably going to think about that quite seriously. (Participant \#9)

\section{Capital}

Women developed a range of career capitals, with particular combinations of capital being considered important for career enhancement. In particular, while human and psychological capitals were necessary for women to develop strategies for navigating their organizational fields, human and social capital interacted to influence career advancement at later stages in women's careers.

Both human capital and psychological capital were thought to help mitigate the prevailing biases (illusio) in the field. In line with Fitzsimmons et al (2016a), self-awareness and selfmanagement emerged as key constructs, along with self-efficacy, leadership, openness to learning, cognitive skills and change-readiness.

The part of knowing what you lack is extremely important as a woman. Because what limits you is your mind, yourself, rather than the environment or the people around you. Yes, how we are raised or the communities we are raised in does impact us at a certain level, but the more we grow in our knowledge, the more we start putting our own perception on who we are, who we want to be. And that can drive us in work and in life. (Participant \#5) 
Participants also acknowledged the significance of emotional intelligence, as a manifestation of psychological capital. Emotional Intelligence helped participants to adopt behaviours that were less defensive, a skill that was considered doubly significant in a multi-cultural context, and important for succeeding in their organization.

I try to maintain my composure, especially in a business environment. But if you have pushed the wrong buttons, I'm going to let you know that you've pushed the wrong buttons. A lot of times, when the situations come up, I have to walk away and address them later because addressing them sometimes at that moment, it's too heightened and there's going to be too big of a conflict. (Participant \#7)

Cultural capital, acquired as part of early habitus formation, was considered exceptionally important in the context of our study. Later in the participants' careers, their cultural capital was a significant factor in earning credibility and respect in patriarchal, male-dominated environments. Our findings indicate that both men and women shared the value assigned to cultural capital. This positively influenced the ability of the women to overcome many of the barriers to their career advancement. Unlike most of the other capitals, cultural capital was not devalued in the organizational field. It provided legitimisation for the women, validating, to some extent, their perceived value of the other capitals they possessed. However, our findings also indicate that, if women did not respect their cultural capital, their career advancement endeavours would suffer. Participants, therefore, noted that they would never trivialise their cultural legacy.

[You've] to be very careful in your actions and you have to be professional. Especially, you know, dealing with fellow men of the same nationality. So, I mean, you cannot, you know, your decorum should be very, conservative. (Participant \#3) 


\section{Evolving Career Capital Configurations, Habitus, and Reflexivity}

The findings suggest that human capital (competence and integrity dimensions) combined in unique ways with cultural capital to help legitimize the value of the women's other capitals, and align their habitus with that of the organizational actors. As noted, an obligation to conform to cultural heritage was an overriding theme in the study. Thus, women strove to overcome prejudices held by the dominant cohort through building strong human capital, at the same time, conforming with its expectations relating to culture. In navigating this 'dual' position, the women emphasized the importance of showing dignity, and ensuring that no cultural boundaries were broken in pursuing their career goals. In addition, the combination of psychological and cultural capital gave women a strong sense of obligation and a persevering attitude. This was evident in their willingness to work harder than their male counterparts, in order to prove themselves in their jobs. Although this perpetuated the stereotype, and placed an extra burden on the women to perform, they acknowledged that they generally had little choice. As noted by Kirchmeyer (1998), women invariably get less return on investment on their human capital than men; hence the need to always work harder to achieve the same outcome.

I think the most important way I earned credibility was that I used to always over deliver because I always felt, and maybe not just felt, I needed - it's an actual need - to prove myself. I felt always under pressure to over deliver. (Participant \#14)

A change in employment, joining a new organization, or starting a business, reflected a change in the field. Participants showed a strong readiness to develop new capitals and reframe their habitus to align with the new field, and ensure that the capital they owned and developed had value. Joy et al (2018) notes how migrants face similar needs in reframing their habitus, and develop new, or new combinations of, capitals to meet the expectations of new social and 
organizational fields. Many participants demonstrated fearlessness in exposing themselves to unfamiliar contexts. They were prepared to take risks, while still using learning opportunities to acquire new skills and increase self-efficacy.

A lot of people tend to stick to one end or to a portion of that. I want to explore the full range. And until I do, I don't know what I'm capable of doing. (Participant \#3)

\begin{abstract}
Also,
If I would find a word to describe my journey, I would say 'change'. Because I'm not that kind of person who you could put in a template. I like creativity. I like changing my path. (Participant \#10)
\end{abstract}

An important finding in our study was that human capital by itself was not a significant predictor of success. Rather, human capital gained potency in career building when combined with social capital. Specifically, in our study, while 'knowing one's job' was considered very important, being seen as 'someone who knows' was even more so. As one participant advised: "You are knocking the door and the door's completely locked. I can find another way. So it's like changing your strategy. It's not about me marketing me, it's about people marketing what I do. When you create successes for the people, they will start spreading the word. And somebody in the top management or at different levels will start hearing that story. And will start meeting on what you do." (Participant \#5)

Social capital has been shown to be particularly important for women and men achieving toplevel and CEO roles (e.g. Adler and Izraeli, 1994; Fitzsimmons et al, 2016). However, women are often disadvantaged, often by exclusion, when trying to build social capital (Metze and Tharenou, 2001). Consequently, women rely more on mentors to build legitimacy (Kirchmeyer, 1998). In our study, mentors and role models were key facilitators for the women 
gaining social capital. These connections helped them to learn how to navigate the dominant power structures in the field through observing and learning, as well as from their own reflections.

My mentor helped me with the networking as well. She is also a woman, has also given me a lot of advice to - how to handle being a woman in this (shipping) industry. She also helped me get into the major events, which has made me known to a lot of people. (Participant \#14)

Formal organizational coaching was perceived to be largely absent in the organizations where the women worked, with some participants suggesting this as a reason why informal mentoring was so valuable. This aligns with existing research showing the lack of formal coaching or mentoring processes in the AME region (Abdalla, 2015). However, so strongly perceived was the need for formal coaching among four of the participants that they later moved into coaching careers, three as self-employed coaches, and one as an internal coach in her organization.

So, I think it's more about empowering women more, by giving them an opportunity to get coaches from either within or outside the organization. (Participant \#5)

These women stressed the importance of coaching for men, particularly at senior levels, as well as for women, in order for women's career building challenges to be understood, and the skills and organizational practices for supporting women leaders to be developed. Where the opportunity for coaching of senior men had arisen, the male recipients were extremely receptive.

...I know he took coaching, he embraced it... I deal with a lot of males - most of my clients who I coach in the organization are senior level males... So [I am working on] 
establishing a coaching department, working on senior leadership, because they are the key. (Participant \#5)

The participants were clearly aware of illusio and doxa, and developed strategies to respond to the power structures in the field. Sponsors further helped the participants get a sense of the game (illusio) and the related stakes. Some women chose to align with sponsors strategically, through influencing those in power and earning their trust. Powerful sponsors, specifically from the dominant cohort, were seen as one of the strongest drivers for participants' sense making of the field (doxa and illusio), and for developing the necessary combinations of capital.

Sometimes, like, they used to joke around and they said, 'oh, sorry, you shouldn't be here. We're having a guy joke.' Some of them wanted on purpose to alienate me. The support is very important from upwards - and leading by example. Like, early in my career, I had a senior manager who always used to highlight women's, virtues in an organizational context, and how they have contributed in different contexts. This helped in breaking the power dynamics (Participant \#2)

Where implicit biases were deep-rooted in the field, the women preferred not to try to change the rules of the game (doxa), but instead play along with the dominant actors in specific situations. Based on their perception that the rules of the game favour the dominant cohort, the participants chose to practise in alignment with the patriarchal expectations prevalent in the field (illusio and doxa). Through this process, the participants believed that, eventually, the stakes in the field would favour them, and give them access to powerful positions, thus turning the field to their advantage. 


\begin{abstract}
I had a functional boss situated in [country] and my local boss was based here. We had a strategic uplift to the company and I invited that functional boss over. He was a big shot. My boss was not really in favour of the idea of me inviting him, as he was really scared of him. I convinced him as to how this could work, and when the functional boss came, it helped. Thus it's also by proving through actual experience and by being assertive and through showing them (bosses) that - 'See? I told you - how this is going to benefit you (rather than myself), how it will benefit stakeholders'. (Participant \#9)
\end{abstract}

The participants challenged the prejudices driven by the tacit beliefs and unconscious assumptions (habitus) of the dominant cohort in their field by adapting their communication style. They first sought to gain credibility based on their cognitive capital, and then focus on advocating for themselves, driven by self-awareness and self-efficacy.

I was aspiring for this coaching leadership position at work with an appropriate title and I realised that creating success stories before asking for the position makes this more feasible, because, they could see the impact of what I was doing and I actively negotiated. (Participant \# 5)

Consistent with other research in different contexts (e.g. Duberely and Cohen, 2010; Fitzsimmons, 2016), our findings show the importance of underlying habitus, and constantly changing and evolving configurations of capital relevant to specific fields. Participants continually reflected on their understanding of the prevalent biases, dominant structures in their organizations, location of the power centres, implicit and explicit rules (doxa), and how the game was played (illusio), in the expectation that they might influence them in appropriate ways to support their own success. In other words, it was essential for them to appreciate how 
the habitus, and, hence, desired capitals, and the field interacted, and the outcomes that prevailed.

I've been in situations where the men around me were trying to top each other. And having to diffuse it. I watched to see who was really leading it, by body language, focusing the attention on that person who is really the decision maker - in theatre we call it power-play. Finding who has the power. Every negotiation, if you watch clearly, there is a moment where the power player might drop the power. Just for a few seconds. And being aware that they just dropped it, and you can catch it. And in theatre there is improvisation. My training in theatre helps. (Participant \#7)

\section{IMPLICATIONS FOR PRACTICE}

Practice, according to Bourdieu (1990), results from the interaction between habitus, capital, and the specific field conditions at the time. The challenges faced by participants in our study indicate clearly that pipeline block was widely experienced, consistent with other findings from the AME region (Karam and Afouni, 2014; Marmenout and Lirio, 2014). Our findings also show that individual women can, and do, successfully develop habiti conducive to the creation of valued capital, and overcome dominant cohorts in the field to achieve senior and leadership positions in the UAE. While most women had benefited from mentoring, they believed that formal, culturally sensitive, organizational coaching could directly address some of the challenges experienced. We, therefore, focus our discussion on the practical implications of coaching in the AME context.

The literature shows that coaching may promote the development of career capital, and, in turn enhance performance (Salomaa and Makela 2017). Coaching does not directly affect the field, but, through listening and questioning, coaching may increase people's awareness of their 
habitus and of the prevailing organizational doxa and illusio. This leads to a better understanding of the types of capital that are valued and the practices that can be deployed to thrive in the field. Coaching women to consciously accumulate valued capital assists them to overcome barriers, take on more demanding roles, and achieve their potential (Bonneywell 2017; Leimon et al, 2010). Multi-level coaching can promote the development of various types of capital: group coaching (Bonneywell, 2017), and peer coaching (Bozer and Joo, 2015) for social capital, and individual coaching for psychological capital, as well as self-awareness and self-efficacy.

Human capital is enhanced by learning, which is facilitated by coaching (Matsuo 2018). Further, the transfer of knowledge from training to the workplace is vastly increased by coaching (Olivero, Bane, and Kopelman, 1997). Career capital is likely to be accumulated in an ad hoc fashion when there is no organizational support (Rodriguez and Scurry, 2014), yet formal coaching or mentoring in Arab organizations is not the norm (Abdalla, 2015; Tlaiss and Kauser, 2010). Our findings support this view, but show the widespread use of informal mentoring and support.

Dissipation of the pipeline block calls for contextually-sensitive HRD strategies (O'Neil, Hopkins and Bilimoria, 2015). As Abalkhail (2019 p.196) notes, “women’s leadership development within the context of Arab countries cannot be pursued in isolation from its social and cultural context." In adopting formal organizational coaching in organizations in the AME, HR departments can ensure that managers responsible for coaching are trained in the necessary skills, and supported in their implementation. This approach aligns with an incipient shift toward a more strategic approach to talent management (McCarthy and Milner 2019), also noted in Dirani's (2018) small scale UAE study. However, to achieve both micro- and the 
meso-level benefits, the training element of coaching by itself is not enough. Ongoing support while managers transfer learned behaviours to the workplace is necessary until the new behaviours become habitual (Grant 2010). By adopting a systematic approach, HR departments can also incorporate flexible working practices (Abalkhail 2019), enabling women to align their career capital with the capital valued in their organization - effectively creating new rules of the game (doxa).

Given the challenging doxa and illusio prevailing in most of the organizations referred to in this study, it is imperative that both implicit and explicit biases be addressed. Coaching can reduce implicit bias, while organizational policies and procedures for recruitment, selection and promotion can address explicit bias.

Aligning coaching with organizational strategy will position women more advantageously than a deficit coaching model seeking to address perceived weaknesses of individual female leaders. An alignment model benefits organizations through matching the best people to appropriate roles, regardless of gender. Enhancement of career capital through coaching, will encourage awareness among both males and females of their own habiti, and the doxa and illusio in their specific fields, increasing the likelihood of career success. Coaching can help women, in particular, to develop or change their own habitus and create the capitals necessary to thrive in the field, given the prevailing doxa and illusio. Organizations should build cultures within organizations that value women's career capitals and legitimize their habiti, at the same time, recognizing the contextual setting. Without such support, the likely outcome is the loss of access to this pool of talent (Murray and Zhang-Zhang 2018).

\section{CONCLUSIONS AND CONTRIBUTIONS}


Our study addresses the issue of pipeline block, where women (in the AME context) are impeded in their career advancement. We explore how context and multi-level factors (individual, meso- and macro-) influence the formation and dissipation of the pipeline block by considering the barriers that women face as they progress in their careers. We used Bourdieu's capital-field-habitus framework (Bourdieu, 1990), also incorporating the less often used elements of doxa and illusio, to ground our conceptualisation and analysis. We also drew upon literatures covering career capital, and HRD (notably coaching) to help frame and interpret our findings.

Four key contributions are proposed. Our first theoretical contribution refers to the identification of the capitals that are important to women's career development in the AME region, specifically the UAE. The importance of constantly evolving and unique configurations of capital and experience is also highlighted. Further, we have shown that the combination of human and social capital is highly valued and has the most leverage at the senior-level in organizations. We also show that the habitus and capitals that women possess are often not valued in their respective organizational fields, because of the collective habiti of the dominant cohort and the doxa and illusio prevalent in the organization. This requires women to understand how these interact and influence organizational practice, and find ways to navigate through and past the impediments.

This brings us to our second theoretical contribution. Our data suggest that cultural capital is key to facilitating women's advancement in predominantly agentic-oriented organizational fields. Cultural capital is deeply rooted in AME societies and is valued by both women and dominant male actors in organizations. We, therefore, suggest that, rather than primarily containing convertible value per se, as do the other capitals, cultural capital acts more as a 
bridge between field and habitus. This may provide insight into why the women have succeeded in their career advancement aspirations within a traditional habitus-field-capital milieu that would presume otherwise. In line with a critical theory approach, what are perceived as undesirable influences of social traditions, such as patriarchy, are neither inevitable nor unavoidable (Adler et al, 2007). By using a unique dual approach, our participants, on the one hand, challenged the traditional barriers to their career progression by exercising agency and carefully navigating their career capital through the dominant tradition-oriented fields, while, on the other hand, balancing this with conformity to strongly held cultural beliefs in their society. Only by having a deep contextual understanding of the inviolable elements of culture in the AME setting, were these women able to develop valuable cultural capital and successfully employ such a dual, push-pull, strategy. Thus, in accordance with critical theory thinking, our study allows us to propose alternative explanations for the phenomenon, without negating the traditional view (Carr, 2006; Brookfield, 2014). A critical theory perspective lends promise to further investigating and understanding this noteworthy finding.

Our findings also add a contextual contribution, since they have not, to our knowledge, been reported before in the AME region. The importance of the Arab context was evident throughout our findings. Increasingly, scholars are calling for the effects of context to be incorporated into research, and for theoretical perspectives to acknowledge context (e.g. Whetten, 2008), including in women and leadership research in the AME region (Jayashree and Lindsay, 2016). It is beyond the scope of this paper to explore this area further, but it is crucial that scholars of women's career development acknowledge the role of context.

Our use of an inductive study and an approach (based on Gioia et al, 2012) that allowed for the convergence of in-depth data-driven insights with literature-based concepts, at the same time 
enabling new concepts to emerge, represents a methodological contribution to this research domain. Previous studies have relied largely on quantitative approaches. Hence, we are responding to the call for more qualitative research on career capital and career experience (Duberley and Cohen, 2010), and build on the research on women's careers of these and other authors. We also contribute methodologically by adding to the very few studies utilising Bourdieu's framework (including the less used doxa and illusio) to examine career capital in relation to gender, following suggestions by Huppatz (2009).

Last, as already discussed, we have proposed the use of formal organizational coaching to assist women in developing the capitals most appropriate for their field, and in using and/or transforming their habitus to leverage the value of these capitals. This represents our practical contribution, which could, with future research, also extend to contributions to HRD/coaching theory. Our data highlight the espoused need for organizational coaching to support women's carer development, justifying continued attention to this issue.

We believe that these contributions collectively address, and add new insights to, the issue of pipeline block. The study reveals the various and complex ways in which the women participants both faced and overcame barriers to their career enhancement - barriers that are similar to those found in much of the general and AME literature. However, the contextual and multi-level overlay to the study also revealed specific issues and nuanced influences that are often overlooked in context-neutral, single-level research. Most importantly, our findings show the criticality of understanding the dynamic and relational nature of habitus, capitals, field, doxa and illusio in influencing the career advancement of women. The use of Bourdieu's framework as an investigative lens has revealed an understanding of the issues underlying pipeline block, but also opens up more avenues of inquiry into this phenomenon. 


\section{LIMITATIONS AND FUTURE RESEARCH}

Although our study included expatriates from different countries within the region, we did not account for intra-regional differences in the contextual influences at play. The heterogeneity among the nations in the AME region is well recognized (Tlaiss, 2015), and differences in cultures and values may, for example, impact women's early habitus development differently. A deeper examination of this through future research could provide a much finer-grained perceptive on the phenomenon. A more contextually-rich approach could further inform related HRD and coaching strategies for organizations.

A related limitation is the assumption of homogeneity among organizations in an organizational field. Since many companies have international origins and may have international staffing, it is vital to take into account the different characteristics of the dominant actors in the field. Future research could compare different types of organizations, including local, international, public and private sector.

Finally, we take note of Bourdieu's insistence on reflexivity, and his key concern regarding the epistemological stance that the researchers take towards social science research (Bourdieu, 2000). In particular, he cautions against the disconnection between practice and the discourse expected to take place with other researchers, whereby the logic of practice becomes lost (Golsorkhi et al, 2010). While acknowledging this concern, we attempted to mitigate these potential biases in a number of ways, by: (i) maintaining a high level of engagement with the data, (ii) using a robust and inductive approach to our analysis and interpretation, and (iii) gaining validation of our interpretations from our participants. Bearing in mind these 
limitations, we hope that our study encourages further work on this crucial topic and in this, as yet, under-researched part of the world. 


\section{REFERENCES}

Abalkhail, J.M. (2019), "Women's career development in an Arab Middle Eastern context", Human Resource Development International, Vol 22, No 2, pp.177-199.

Abdalla, I.A. (2015), "Career facilitators and barriers of Arab women senior executives", International Journal of Business and Management, Vol. 10, No. 8, pp. 218-232.

Adler, P.S., Forbes, L.C., \& Willmott, H. (2007), "Critical management studies”, The Academy of Management Annals, Vol. 1, No. 1, pp. 119-179.

Adler, N.J., \& Izraeli, D. (eds.). (1994), “Competitive frontiers: Women managers in a global economy”. Cambridge, MA: Blackwell. Arnold.

Afiouni, F., Karam, C.M., \& Sidani, Y. (2014), “The Bursting Pipeline: Gender, HR and Avenues for Regional Development in the Arab Middle East"., Academy of Management Annual Meeting Proceedings.

Al Ariss, A., \& Syed, J. (2011), "Capital mobilization of skilled migrants: A relational perspective”, British Journal of Management, Vol. 22, No.2, pp. 286-304.

Al-Nasser, A., \& Behery, M. (2015). "Examining the relationship between organizational coaching and workplace counterproductive behaviors in the United Arab Emirates". International Journal of Organizational Analysis, Vol. 23, No. 33, pp. 378-403.

Almessabi, B.N.A. (2017), "Critical factors in leadership succession planning: securing the human resources future for government organisations in the Abu Dhabi Emirate, UAE”, DBA thesis, Southern Cross University, Lismore, NSW. Copyright B.N.A. Almessabi. Auld, G.W., Diker, A., Bock, A.M., Boushey, C.M., Bruhn, C.M., Cluskey, M., Edlefsen, M., Goldberg, D.L., Misner, S.L., Olson, B.H., Reicks, M., Wang, C. \& Zaghloul, S. (2007), "Development of a Decision Tree to Determine Appropriateness of nVivo in Analyzing Qualitative Data Sets”, Journal of Nutrition Education and Behavior, Vol. 39, No.1, pp.37-47. 
Bernhardt, E. (2000). "Female careers between employment and children”. In paper presented at the seminar, Low fertility, families and public policies, organized by the European Observatory on Family Matters in Sevilla, Spain, September 15-16.

Bonneywell, S. (2017), "How a coaching intervention supports the development of female leaders in a global organization", International Journal of Evidence Based Coaching and Mentoring, Special Issue No. 11, pp. 57-69.

Bourdieu, P. (1977), Outline of a theory of practice, Cambridge University Press, Cambridge.

Bourdieu, P. (1990), The logic of practice, Stanford University Press, Palo Alto.

Bourdieu, P. (2000), Pascalian Meditations. Stanford, CA: Stanford University Press.

Bourdieu, P., \& Wacquant, L. J. (1992), An invitation to reflexive sociology, University of Chicago Press, Chicago, IL.

Bozer, G., \& Joo, B.K. (2015), "The effects of coachee characteristics and coaching relationships on feedback receptivity and self-awareness in executive coaching”, International Leadership Journal, Vol. 7, No. 3, pp.37-57.

Brookfield, S.D. (2014), "Foundations of critical theory", Advances in Developing Human Resources, Vol. 16, No. 4, pp. 417-428.

Carr, A. (2006), "What it means to be 'critical' in relation to international business: a case of the appropriate conceptual lens", Critical Perspectives on International Business, Vol.2, No.2, pp. 79-90.

Cresswell, J.W. (2013), Qualitative Inquiry and Research Design. Choosing Among Five Approaches. $3^{\text {rd }}$ Ed. Sage Publications, London.

Crouch, M. \& McKenzie, H. (2006), “The logic of small samples in interview-based qualitative research", Social Science Information, Vol. 45, No.4, pp.483-499.

DeFillippi, R.J., \& Arthur, M.B. (1996), “Boundaryless contexts and careers: A competencybased perspective". In Arthur M. B. and Rousseau D.M. (Eds.), The boundaryless 
career: A new employment principle for a new organizational era (pp. 116-131). Oxford University Press, Oxford.

Dello Russo, S., Miraglia, M., \& Borgogni, L. (2017), "Reducing Organizational Politics in Performance Appraisal: The Role of Coaching Leaders for Age-Diverse Employees", Human Resource Management, Vol. 56, No. 5, pp. 769-83.

Dirani, K.M. (2018), “Talent Management and Development in the United Arab Emirates", Advances in Developing Human Resources, Vol. 20, No. 4, pp. 479- 497.

Duberley, J., \& Cohen, L. (2010). “Gendering career capital: An investigation of scientific careers". Journal of Vocational Behavior, Vol. 76, No. 2, pp. 187-197.

Eagly, A.H., \& Heilman, M.E. (2016). “Gender and leadership: Introduction to the special issue”. The Leadership Quarterly, Vol. 27, No.3, pp.349-353.

Edmondson, A.C., \& McManus, S.E. (2007). "Methodological Fit in Management Field Research”. Academy of Management Review, Vol. 32, No.4, pp.1155-1179.

Elbanna, S. (2010), “Strategic planning in the United Arab Emirates", International Journal of Commerce and Management, Vol. 20, No. 1, pp. 26-40.

Ellinger, A.D. \& Kim, S. (2014), “Coaching and Human Resource Development: Examining Relevant Theories, Coaching Genres, and Scales to Advance Research and Practice”, Advances in Developing Human Resources, Vol. 16, No. 2, pp. 127-38.

Erel, U. (2010). "Migrating cultural capital: Bourdieu in migration studies". Sociology, Vol. 44, No. 4, pp.642-660.

Fitzsimmons, T., Callan, V., \& Paulsen, N. (2014). “Gender disparity in the C-suite: Do male and female CEOs differ in how they reached the top?” The Leadership Quarterly, Vol. 25, No. 2, pp. 245-266.

Fitzsimmons, T.W., \& Callan, V.J. (2016), “CEO selection: A capital perspective”. Leadership Quarterly, Vol. 27, No. 5, pp.765-787. 
Fitzsimmons, T.W., \& Callan, V.J. (2016a), "Applying a capital perspective to explain continued gender inequality in the C-suite". The Leadership Quarterly, Vol. 27, No.3, pp.354 -370 .

Fligstein, N., \& McAdam, D. (2011). "Toward a general theory of strategic action fields". Sociological Theory, Vol. 29, No.1, pp.1-26.

Forstenlechner, I., Madi, M., Selim, H.M., \& Rutledge, E.J. (2012). “Emiratisation: determining the factors that influence the recruitment decisions of employers in the UAE”. International Journal of Human Resource Management, Vol. 23. No. 2, pp. $406-421$.

Gioia, D. A., Corley, K. G., \& Hamilton, A. L. (2012). “Seeking Qualitative Rigor in Inductive Research: Notes on the Gioia Methodology”. Organizational Research Methods, Vol. 1, No. 1, pp. 15-31.

Glaser B.G. and Strauss, A.L. (1967). "The Discovery of Grounded Theory”, Aldine de Gruyter, New York, NYGlover, J., Champion, D., Daniels, K., \& Boocock, G. (2016). "Using capital theory to explore problem solving and innovation in small firms". Journal of Small Business and Enterprise Development, Vol. 23, No 1, pp. 25-43.

Golsorkhi, D., Leca, B., Lounsbury, M., \& Ramirez, C. (2009). “Analysing, accounting for and unmasking domination: On our role as scholars of practice, practitioners of social science and public intellectuals". Organization, Vol. 16, No.6, pp. 779-797.

Gormley, H., \& van Nieuwerburgh, C. (2014), "Developing coaching cultures: a review of the literature", Coaching: An International Journal of Theory, Research and Practice, Vol. 7, No. 2, pp. $90-101$.

Grant, A.M. (2010), "It takes time: a stages of change perspective on the adoption of workplace coaching skills", Journal of Change Management, Vol. 10 No. 1, pp. 61-77. 
Hagen, M., \& Gavrilova Aguilar, M. (2012), “The impact of managerial coaching on learning outcomes within the team context: An analysis", Human Resource Development Quarterly, Vol. 23, No. 3, pp. 363-88.

Huppatz, K. (2009). “Reworking Bourdieu's 'capital': Feminine and female capitals in the field of paid caring work". Sociology, Vol. 43, No. 1, pp. 45-66.

Hutchings, K., Lirio, P., \& Metcalfe, B. D. (2012), “Gender, globalization and development: a re-evaluation of the nature of women's global work. The International Journal of Human Resource Management”, Vol. 23, No.9, pp. 1763-1787.

Iellatchitch, A., Mayrhofer, W., \& Myer, M. (2003). “Career fields: A small step towards a grand theory?" International Review of Human Resource Management, Vol.14, pp. $728-750$.

ILO (2018). International Labour Organization. World Employment Social Outlook Trends, pp. 1-82. Available at url https://www.ilo.org/wcmsp5/groups/public/---dgreports/--dcomm/---publ/documents/publication/wcms_615594.pdf. Accessed 21-12-2019.

Jayashree, P., \& Lindsay, V. (2016), “Attainment and enactment of leadership among women in the United Arab Emirates: Proposing relevant theoretical foundations”, International Journal of Work Organization and Emotion, Vol. 7, No. 3, pp. 224-240.

Joy, S., Game, A.M., \& Toshniwal, I.G. (2018), “Applying Bourdieu’s capital-field-habitus framework to migrant careers: taking stock and adding a transnational perspective" The International Journal of Human Resource Management, pp. 1-24, http://www.tandfonline.com/action/showCitFormats?doi=10.1080/09585192.2018.14 $\underline{54490 .}$

Karam, C. M., \& Afiouni, F. (2014). 'Localizing women's experiences in academia: multilevel factors at play in the Arab Middle East and North Africa", The International Journal of Human Resource Management, Vol. 25, No.4, pp.500-538. 
Karam, C.M., \& Jamali, D. (2013). "Gendering CSR in the Arab Middle East: An Institutional Perspective”, Business Ethics Quarterly, Vol. 23, No. 1, pp. 31 - 68.

Kelly, P., \& Lusis, T. (2006). "Migration and the transnational habitus: Evidence from Canada and the Philippines", Environment and Planning, Vol. 38 No. 5, pp.831-847.

Kemp, L. J., Madsen, S. R., \& Davis, J. (2015). “Women in business leadership: A comparative study of countries in the Gulf Arab states", International Journal of Cross Cultural Management, Vol 15, No. 2, pp. 215-233.

Kirchmeyer, C. (1998). "Determinants of managerial career success: evidence and explanation of male/female differences", Journal of Management, Vol. 24, pp. 673-692.

Klima, C. (2015), "Coaching UAE nationals in leadership positions”, in C Van Nieuwerburg, C. and Allaho, R. (Eds), Coaching in Islamic Culture: The Principles and Practice of Ershad, Karnac, London, pp. 120-3.

Koroleva, N. (2016). “A new model of sustainable change in executive coaching: Coachees' attitudes, required resources and routinisation". International Journal of Evidence Based Coaching and Mentoring, Vol. 10, pp. 84-97.

Lawler, S. (2005). "Rules of Engagement: Habitus, Power and Resistance”. The Sociological Review, Vol. 52, No.2_suppl, pp. 110-128.

Leimon, A., Moscovici, F., \& Goodier, H. (2010), Coaching women to lead, Routledge.

Lin, W-J., Lin, C-Y., \& Chang, Y-H. (2017), "The impact of coaching orientation on subordinate performance: the moderating effects of implicit person theory and LMX", Asia Pacific Journal of Human Resources, Vol. 55, No. 1, pp. 86-105.

Lovell, T. (2000), “Thinking feminism with and against Bourdieu”, Feminist Theory, Vol. 1, No. 1, pp.11-32. 
Marmenout, K., \& Lirio, P. (2014). "Local female talent retention in the Gulf: Emirati women bending with the wind”. The International Journal of Human Resource Management, Vol. 25, No. 2, pp.144-166.

Matsuo, M. (2018), "How does managerial coaching affect individual learning? The mediating roles of team and individual reflexivity", Personnel Review, Vol. 47, No. 1, pp. 11832.

Mayrhofer W., Meyer, M., Steyrer, J., Maier, J., \& Herman, A. (2004), “Thick descriptions of career habitus: Agency and structure in career fields". In Paper presented to EGOS Colloquium Ljubljana, Slovenia, July 4th-6th.

McCarthy, G. (2014), Coaching and Mentoring for Business. Sage London.

McCarthy, G., \& Milner, J. (2019), “Ability, motivation and opportunity: managerial coaching in practice", Asia Pacific Journal of Human Resources, Early Cite available at https://onlinelibrary.wiley.com/doi/full/10.1111/1744-7941.12219.

McDaniel, E., \& DiBella-McCarthy, H. (2012), "Reflective leaders become causal agents of change", Journal of Management Development, Vol. 31, No. 7, pp. 663-671.

Metz, I., \& Tharenou, P. (2001), “Women's career advancement”. Group and Organization Management, Vol. 26, No. 3, pp. 312-342.

Miles, M.B., \& Huberman, A.M. (2004), Qualitative Data Analysis: An Expanded Sourcebook. $2^{\text {nd }}$ Ed. Sage Publications, CA.

Mohamed, A., \& Mohamad, M. (2011), “The effect of wasta on perceived competence and morality in Egypt", Cross Cultural Management, Vol. 18, pp. 412-25.

Murray, J.Y \& Zhang-Zhang, Y. (2018), “Insights on women's labor participation in Gulf Cooperation Council countries”, Business Horizons, Vol. 61, No. 5, pp. 711-20. 
Olivero, G, Bane, K.D., \& Kopelman, R.E. (1997), "Executive coaching as a transfer of training tool: effects on productivity in a public agency", Public Personnel Management, Vol. 26, No. 4, pp. 461- 469.

O’Neil D.A., Hopkins, M.M., \& Bilimoria, D. (2015), “A framework for developing women leaders: applications to executive coaching", The Journal of Applied Behavioral Science, Vol. 51, pp.253-276.

Palmer, T., \& Arnold, V.J. (2013), "Coaching in the Middle East", in Passmore, J. (Ed.), Diversity in Coaching, 2nd ed, Kogan Page, London, pp. 111-26.

Rayfield, J. (2019). “Addressing disparity in Middle East Female Labor Force Participation: Migrant Child Care in Jordan”. Hemispheres: Global Visions, Local interests. Vol. 42, pp. $119-135$.

Renkema, M., Meijerink, J., \& Bondarouk, T. (2017), “Advancing multilevel thinking in human resource management research: Applications and guidelines.” Human Resource Management Review, Vol. 27, No. 3, pp. 397-415.

Rodriguez, J.K., \& Scurry, T. (2014), “Career capital development of self-initiated expatriates in Qatar: cosmopolitan globetrotters, experts and outsiders", International Journal of Human Resource Management, Vol. 25, No. 7, pp. 1046-1067.

Rousseau, D. M., \& Fried, Y. (2001), "Location, location, location: Contextualizing organizational research”. Journal of Organizational Behavior, Vol. 22 No. 1, pp.1-13.

Salomaa, R., \& Makela, L. (2017), “Coaching for career capital development: A study of expatriates' narratives", International Journal of Evidence Based Coaching and Mentoring, Vol. 15, No. 1, p. 114.

Sidani, Y.M., Konrad, A., \& Karam, C.M. (2015). "From Female Leadership Advantage to Female Leadership Deficit: A developing country perspective".Career Development International, Vol. 20, No. 3, pp. 273-292. 
Silva, E., \& Edwards, R. (2004). “Operationalizing Bourdieu on capitals: A discussion on the construction of the object”. In ESRC Research Methods Programme working paper. Available from http://www.ccsr.ac.uk/methods/publications/documents/WP7.pdf

Strauss, A., \& Corbin, J. (1998). Basics of Qualitative Research: Techniques and Procedures for Developing Grounded Theory, $2^{\text {nd }}$ ed., Sage, Newbury Park, CA.

Taymor, A. (1986), Al Amthal Al Amaiah, Alaharm Press, Cairo.Tharenou, P., Latimer, S., \& Conroy, D. (1994). "How do you make it to the top? An examination of influences on women's and men's managerial advancement". Academy of Management Journal, Vol. 37, No. 4, pp. 899-931.

The Global Gender Gap Report (2020). World Economic Forum. http://www3.weforum.org/docs/WEF_GGGR_2020.pdf. Accessed 21/01/20

Thornton, G. (2019). "Women in business: building a blueprint for action." https://www.grantthornton.global/globalassets/global-insights---do-notedit/2019/women-in-business/gtil-wib-report_grant-thornton-spreads-low-res.pdf. Accessed 21/01/20.

Tlaiss, H.A. (2013). "Women managers in the United Arab Emirates: successful careers or what?” Equality, Diversity and Inclusion: An International Journal, Vol. 32, No. 8, pp. 756-776.

Tlaiss, H.A. (2014a), "Between the traditional and the contemporary: careers of women managers from a developing Middle Eastern country perspective". The International Journal of Human Resource Management, Vol. 25, No. 20, pp. 2858-2880.

Tlaiss, H.A. (2014b). "Conformers, fighters and rebels: the unfolding of the careers of women in the United Arab Emirates”. Human Resource Development International, Vol. 17, No. 3, pp. 339-357. 
Tlaiss, H. (2015), "Neither-nor: career success of women in an Arab Middle Eastern context”. Employee Relations, Vol. 37, No. 5, pp. 525-546.

Tlaiss, H., \& Kauser, S. (2010), "Perceived organizational barriers to women's career advancement in Lebanon", Gender in Management: An International Journal, Vol. 25, No. 6, pp. 462-496.

UAE Embassy (2019). https://www.uae-embassy.org/about-uae/women-uae. Accessed $21 / 01 / 20$

Whetten, D.A. (2008), “An examination of the interface between context and theory applied to the study of Chinese organizations", Management and Organization Review,Vol. 5, No.1, pp. 29-55.

Yin, R. K. (2014), Case study research: Design and methods, (5th ed.). Los Angeles, Sage.

Yu, Y., \& Lindsay, V. J. (2017). A social-psychological perspective of host country societal acceptance of foreign firms. Critical Perspectives on International Business, Vol. 13, No. 4, pp. 297-318. 
Table 1: Participant Characteristics

\begin{tabular}{|c|c|c|c|c|c|c|c|}
\hline \begin{tabular}{|l} 
Participant \\
Number
\end{tabular} & $\begin{array}{l}\text { Age } \\
\text { Bracket }\end{array}$ & Nationality & Designation & $\begin{array}{l}\text { Family } \\
\text { status }\end{array}$ & $\begin{array}{l}\text { Years' } \\
\text { work } \\
\text { experience } \\
\end{array}$ & Industry & Sector \\
\hline 1 & $50-60$ & Saudi-Arabia & CEO & $\begin{array}{l}\text { Married with } \\
\text { children }\end{array}$ & 27 & Health & Private \\
\hline 2 & $30-40$ & Saudi Arabia & Banker & $\begin{array}{l}\text { Married with } \\
\text { Children }\end{array}$ & 19 & $\begin{array}{l}\text { Banking and } \\
\text { Financial } \\
\text { Services }\end{array}$ & Private \\
\hline 3 & $60-70$ & UAE & $\begin{array}{l}\text { Entrepreneur } \\
\text { (Founder CEO) }\end{array}$ & $\begin{array}{l}\text { Married with } \\
\text { Children }\end{array}$ & 40 & Education & Private \\
\hline 4 & $40-50$ & UAE & $\begin{array}{l}\text { Executive Vice } \\
\text { President }\end{array}$ & $\begin{array}{l}\text { Married with } \\
\text { Children }\end{array}$ & 25 & $\begin{array}{l}\text { Banking and } \\
\text { Financial } \\
\text { Services } \\
\end{array}$ & Private \\
\hline 5 & $40-50$ & Jordan & $\begin{array}{l}\text { Global Director } \\
(\mathrm{HR})\end{array}$ & $\begin{array}{l}\text { Married with } \\
\text { Children } \\
\end{array}$ & 28 & $\begin{array}{l}\text { Logistics } \\
\text { Services } \\
\end{array}$ & Private \\
\hline 6 & $50-60$ & Lebanon & Partner & $\begin{array}{l}\text { Married with } \\
\text { Children }\end{array}$ & 26 & Law Firm & Private \\
\hline 7 & $30-40$ & Ghana & Entrepreneur & Single & 18 & Leather & $\begin{array}{l}\text { Family } \\
\text { Business } \\
\end{array}$ \\
\hline 8 & $60-70$ & UAE & $\begin{array}{l}\text { Managing } \\
\text { Director }\end{array}$ & $\begin{array}{l}\text { Married with } \\
\text { Children }\end{array}$ & $30+$ & $\begin{array}{l}\text { Multiple } \\
\text { sectors }\end{array}$ & $\begin{array}{l}\text { Family } \\
\text { Business }\end{array}$ \\
\hline 9 & $30-40$ & Egypt & $\begin{array}{l}\text { Marketing } \\
\text { Head }\end{array}$ & $\begin{array}{l}\text { Married with } \\
\text { Children }\end{array}$ & 18 & $\begin{array}{l}\text { Multiple } \\
\text { Sectors }\end{array}$ & $\begin{array}{l}\text { Family } \\
\text { Business }\end{array}$ \\
\hline 10 & $30-40$ & Jordan & $\begin{array}{l}\text { Regional } \\
\text { Communication } \\
\text { and Marketing } \\
\text { Director }\end{array}$ & Married & 16 & $\begin{array}{l}\text { Global Eng, } \\
\text { Management } \\
\& \\
\text { Development } \\
\text { Consultants } \\
\end{array}$ & Private \\
\hline 11 & $40-50$ & UAE & $\begin{array}{l}\text { Head, } \\
\text { Programme } \\
\text { Unit }\end{array}$ & $\begin{array}{l}\text { Married with } \\
\text { Children }\end{array}$ & 25 & Development & $\begin{array}{l}\text { International } \\
\text { non-profit }\end{array}$ \\
\hline 12 & $40-50$ & Sudan & $\begin{array}{l}\text { Senior } \\
\text { Manager for } \\
\text { Programs and } \\
\text { Production } \\
\end{array}$ & $\begin{array}{l}\text { Single } \\
\text { Parent }\end{array}$ & 23 & Media & Private \\
\hline 13 & $30-40$ & Bahrain & $\begin{array}{l}\text { Deputy } \\
\text { Managing } \\
\text { Director }\end{array}$ & Single & 9 & $\begin{array}{l}\text { Shipping } \\
\text { Service }\end{array}$ & $\begin{array}{l}\text { Family- } \\
\text { Business }\end{array}$ \\
\hline 14 & $40-50$ & Morocco & $\begin{array}{l}\text { Director } \\
\text { General }\end{array}$ & $\begin{array}{l}\text { Married with } \\
\text { Children }\end{array}$ & 20 & $\begin{array}{l}\text { Applied } \\
\text { Research } \\
\text { Services }\end{array}$ & $\begin{array}{l}\text { International } \\
\text { non-profit }\end{array}$ \\
\hline
\end{tabular}


Figure 1: Data Structure from the Study (following the Gioa et. al. (2012) method)

Ist order concepts

- Strong support of father in early childhood

- Family environment with no distinction between boys and girls

- School provided an environment that lowered inhibition

- Inspirational women in the family

- Aspirations for a career that provided room for growth and learning

- Early opportunities to exercise leadership in the work context, supported by mentors

- Early adversity and challenge drivers for seeking new opportunities

- knowing what you lack is extremely important as a woman, Inherent belief of not being less than men;

- Continuous learning; always being change-ready

- Fearless in a respectful way; know your decorum, be very conservative especially when working with local men, to earn respect

- Not only work harder, but they (women) have to show their capabilities (be visible); never felt like an impostor

- family fabric very important in GCC; No access to social nurseries or extended families for expat women; cultural expectations regarding motherhood

- Reluctance of senior managers to promote women, as growth seen by dominant cohort as interfering with familial duties;

- $\quad$ Earning credibility through over delivering; Fearlessness and risk-taking;

- Actively managing perceptions in a culturally nuanced manner; navigating emotions to get power position, learnt to pull back at the points where one was not being effective; not making it a zero-sum game; maintaining composure

- Building yourself as a brand through accessing relevant Networks, choosing projects that have visibility, active neaotiation with kev decision-makers buildina on 2nd order themes

Aggregate Dimensions

Habitus
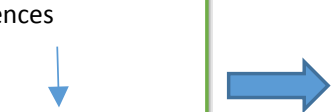

Early Career Experiences

Psychological Capital - Self-awareness, self-efficacy Human Capital - strategy, leadership, cognitive skills, integrity, stewardship

\section{Cultural Capital}

Social Capital - Visibility

Role incongruity and traditional gender role stereotypes Perceived lack of fit

Lack of access to opportunities for building favoured capital

Institutional processes not favouring work-life balance

Pychological capital intersecting with Human capital to Pelp naviga

Human capital gaining potency when combined with Social Capital, later in Career

Human, Psychological Capital and Social Capital gained potency when combined with Cultural Capital

Powerful Male Sponsors helped to understand illusio (how game is plaved) and doxa (rules)

\section{Drivers of Capital}

Formation

\section{Types of Career \\ Capital}

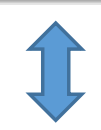

Factors affecting pipeline block

Field, Ilusio, Doxa

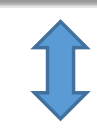

Mitigators of Pipeline Block

Practise 
Figure 2: Career Capital: Drivers and Outcomes

\section{Drivers of Capital Formation}

Mitigators of

Pipeline Block

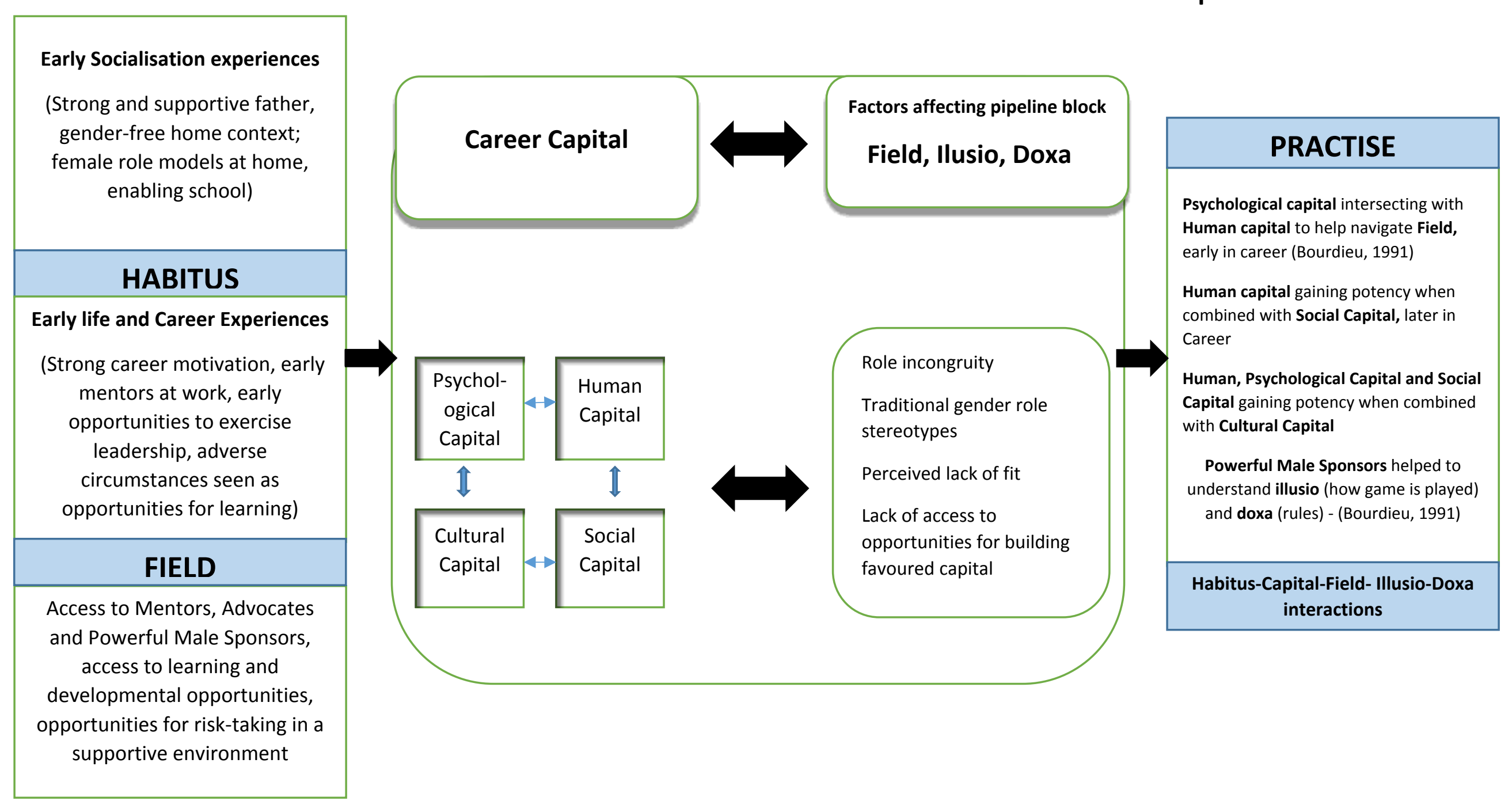

